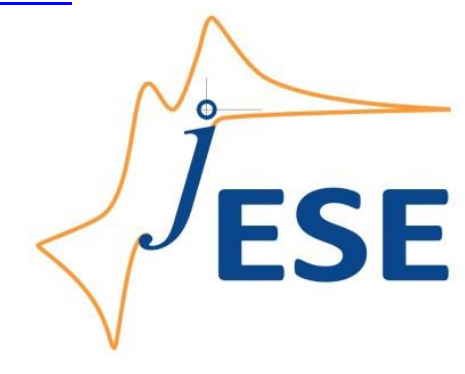

Open Access : : ISSN 1847-9286

www.jESE-online.org

Original scientific paper

\title{
The optimization of an electrochemical aptasensor to detect RBD protein S SARS-CoV-2 as a biomarker of COVID-19 using screen-printed carbon electrode/AuNP
}

\author{
Arum Kurnia Sari ${ }^{1}$, Yeni Wahyuni Hartati ${ }^{1,2,}$, Shabarni Gaffar ${ }^{1,2}$, Isa Anshori ${ }^{3}$, \\ Darmawan Hidayat ${ }^{4}$, Hesti Lina Wiraswati ${ }^{5}$ \\ ${ }^{1}$ Department of Chemistry, Faculty of Mathematics and Natural Sciences, Universitas Padjadjaran, \\ Indonesia \\ ${ }^{2}$ Moleculer Biotechnology and Bioinformatics Research Center, Universitas Padjadjaran, Indonesia \\ ${ }^{3}$ Lab-on-Chip Group, Biomedical Engineering Department, Bandung Institute of Technology, \\ Indonesia \\ ${ }^{4}$ Department of Electrical Engineering, Faculty of Mathematics and Natural Sciences, Universitas \\ Padjadjaran, Indonesia \\ ${ }^{5}$ Department of Parasitology, Faculty of Medicine, Universitas Padjadjaran, Indonesia \\ Corresponding author: ${ }^{凶}$ yeni.w.hartati@unpad.ac.id; Tel.: +628122132349 \\ Received: December 7, 2021; Accepted: February 8, 2022; Published: February 21, 2022
}

\begin{abstract}
Severe acute respiratory syndrome coronavirus 2 (SARS-CoV-2) is the virus identified as the cause of the Coronavirus Disease 2019 (COVID-19) outbreak. The gold standard for detecting this virus is polymerase chain reaction (PCR). The electrochemical biosensor method can be an alternative method for detecting several biomolecules, such as viruses, because it is proven to have several advantages, including portability, good sensitivity, high specificity, fast response, and ease of use. This study aims to optimize an electrochemical aptasensor using an AUNP-modified screen-printed carbon electrode (SPCE) with an aptamer to detect RBD protein S SARS-CoV-2. Aptasensors with the streptavidin-biotin system were immobilized on the SPCE/AuNP surface via covalent bonding with linkers to 3-mercaptopropionic acid (MPA) and electrochemically characterized by the $\left[\mathrm{Fe}(\mathrm{CN})_{6}\right]^{3-14-}$ redox system using differential pulse voltammetry. The results showed that the immobilized aptamer on the SPCE/AUNP electrode surface experienced a decrease in current from 11.388 to $4.623 \mu A$. The experimental conditions were optimized using the Box-Behnken experimental design for the three factors that affect the current response. The results of the optimization of the three parameters are the concentration of aptamer, incubation time of aptamer, and incubation time of RBD protein S SARS-CoV-2, each of which is $0.5 \mu \mathrm{g} / \mathrm{mL}, 40$ minutes, and 60 minutes, respectively. The RBD protein S SARS-CoV-2 with various concentrations was tested on an electrochemical aptasensor to determine the detection
\end{abstract}


limit and quantification limit, and the respective results were 2.63 and $7.97 \mathrm{ng} / \mathrm{mL}$. The electrochemical aptasensor that has been developed in this study can be applied to detect RBD protein S SARS-COV-2 as a COVID-19 biomarker in a simple, practical, and sensitive way.

\section{Keywords}

Box-Behnken design, 3-mercaptopropionic acid, differential pulse voltammetry, portability, fast response

\section{Introduction}

SARS-CoV-2 is a positive single-strand RNA virus with a size of $29.9 \mathrm{~kb}$, which is responsible for the COVID-19 disease. Based on the phylogenetic analysis, SARS-CoV-2 is included in the betacoronavirus of the subgenus Sarbecovirus. SARS-CoV-2 has four structural proteins, namely spike protein (S), membrane protein (M), an envelope protein (E), and nucleocapsid protein (N), which are integrated into the phospholipid bilayer [1,2]. The $S$ protein consists of two functional subunits, namely the $S_{1}$ subunit, which is responsible for attaching the virus to receptors on the host cell surface via the receptorbinding domain (RBD), and the $S_{2}$ subunit, which is responsible for the fusion of the viral membrane with the host cell to facilitate the entry of the virus into the host cell $[3,4]$. As a result, the RBD protein $S$ SARS-CoV-2 has emerged as a prime target for diagnosis, treatment, and vaccination [5].

Currently, there are several types of methods used to detect SARS-CoV-2, such as molecular tests based on detection of viral RNA, antigen tests based on detection of viral proteins, and antibody tests based on detection of specific antibodies against viral proteins. Reverse Transcription Polymerase Chain Reaction (RT-PCR) is the gold standard method for the detection of SARS-CoV-2 virus RNA. The main limitations of this method are the expensive equipment requirements and the need for highly qualified experts. The molecular technique necessitates a lengthy sample processing time, as well as complex and expensive facilities. Lateral Flow Immunoassays (LFIAs) provide a faster response but have lower sensitivity [6]. Meanwhile, detection methods targeting antibodies based on Enzyme-linked Immunosorbent Assay (ELISA) are not suitable for early diagnosis because most patients have antibody responses around 7 to 21 days after infection $[7,8]$.

The electrochemical biosensor has been widely used to detect a variety of biomolecules, such as viruses [9]. Biosensors have been shown to have many benefits, including portability, ease of use, quick response, high sensitivity, and high specificity $[10,11]$. Antibodies, aptamers, and nucleic acids, among some other bioreceptors, can be well immobilized on the electrode surface for detection purposes [9].

Electrochemical biosensor methods have also been reported to be used for the detection of SARS-CoV-2 by using various bioreceptors, such as antibodies [12-15], ssDNA [16,17], antigens $[18,19]$, and aptamers $[20,21]$.

The aptamer is a single-stranded DNA or RNA nucleic acid molecule selected through an in vitro method known as Systematic Evolution of Ligands by Exponential Enrichment (SELEX) [22], which can bind to various targets with high selectivity and specificity, such as metal ions, small molecules, proteins, amino acids, peptides, microorganisms, cells, viruses, and other nucleic acids [23-25]. Compared with antibodies, aptamers have several advantages, namely smaller size, thermal stability, high affinity, excellent sensitivity, easy synthesis, lower toxicity, and easy chemical modification [22]. Biosensors that utilize aptamers as identification elements are referred to as aptasensors. An aptamer for SARS-CoV-2 has been reported by Song et al. [5] of the SELEX method that binds to the RBD protein S SARS-CoV-2. The RBD protein S SARS-CoV-2 and the aptamer CoV2-RBD form hydrogen bonds with the amino acids of the RBD protein S SARS-CoV-2 [5]. 
Aptamer immobilization technique is another critical step in the development of electrochemical aptasensors because it has a significant impact on the overall performance of an aptasensor. Immobilization is used to attach or conjugate a bioreceptor to a transducer. The most commonly used aptamer immobilization technique is physical adsorption and covalent bonding, such as selfassembled monolayers (SAM) with thiol-based interactions, streptavidin-biotin interactions, and surface activation with EDC/NHS [26-28]. Abrego-Martinez et al. [21] report an aptamer-based biosensor developed using a screen-printed carbon electrode for the detection of SARS-CoV-2. Aptamer immobilization on screen-printed carbon electrode modified gold nanoparticles (AuNPs) through self-assembled monolayer (SAM), a thiol-based interaction formed spontaneously by incubation at $4{ }^{\circ} \mathrm{C}$ for 8 hours. Idili et al. [21] also reported an electrochemical aptamer-based (EAB) sensor capable of quantifying the SARS-CoV-2 spike (S) protein using a standard three-electrode cell with a platinum counter electrode and an $\mathrm{Ag} / \mathrm{AgCl}(3 \mathrm{M} \mathrm{KCl})$ reference electrode. Aptamer immobilization through self-assembled monolayer (SAM), namely thiol-based interaction on the surface of gold electrodes.

Despite some complexity in the procedure, the aptamer immobilization via streptavidin-biotin interaction has been chosen based on the known advantages of the methodology. These include the need for very low amounts of biotinylated aptamer, the fact that it is less affected by changes in buffer concentration, $\mathrm{pH}$, denaturants, and high temperatures, as well as the decrease of non-specific adsorption and improvement of the signal-noise ratio. However, it is important to mention that other options could have been evaluated to immobilize the aptamer onto the gold electrode surface, such as via an Au-S bond [27]. In addition, Liebana and Drago. [29] study on Bioconjugation and stabilization of biomolecules in biosensors stated that the characteristics of immobilization methods based on bioaffinity such as streptavidin-biotin have advantages such as good orientation, high specificity, high selectivity, high functionality, and well-controlled [29]. The streptavidin-biotin interaction is used in the aptamer immobilization technique, which is based on the specific affinity of streptavidin and biotin. Streptavidin immobilization on the electrode surface can be achieved through the MPA linker (3-mercaptopropionic acid). MPA is an organosulfur compound that can bind to gold through Au-S bonds. The other terminal end of MPA is the carboxylate group, so the carboxyl group can chemically bind to other groups [30].

Most analytical methods face the problem of time and high reagent consumption, which can be caused by the procedure for determining the optimal conditions of a study that requires many experiments with sufficient numbers. This is especially detrimental in terms of cost, materials, and time. An approach with a chemometric method can be used to solve this problem. This method assesses the significant factors that will affect the response [31,32]. Amongst the tools for the analysis of chemometrics, the Box-Behnken is able to actualize optimization of processes through the implementation of fewer test sets. Moreover, Box-Behnken allows the determination of interactive effects and the measurement of the effect level of parameters [33]. In the biosensor, the incubation time and the stability of the biomolecules on the electrode surface were the most important parameters. The optimum incubation time determines the time required to bond completely to the electrode surface. When the incubation time is lower, it will result in an imperfect bond. Meanwhile, if the incubation time is too long. This will cause the bonds to become saturated [34]. So, using the differential pulse voltammetry, the effect of bioreceptor incubation time, bioreceptor concentration, and target analyte incubation time on this electrochemical aptasensor current response was determined electrochemically with $\mathrm{K}_{3}\left[\mathrm{Fe}(\mathrm{CN})_{6}\right]$ redox system. 
In this study, an electrochemical aptasensor method was developed to detect the RBD protein S SARS-CoV-2 as a biomarker of COVID-19 disease. The aptamer will then bind to the RBD protein S SARS-CoV-2, which can be detected electrochemically with the $\mathrm{K}_{3}\left[\mathrm{Fe}(\mathrm{CN})_{6}\right]$ redox system using the differential pulse voltammetry. Furthermore, the optimum experimental conditions were determined and a standard RBD protein S SARS-CoV-2 test was carried out with various concentrations to determine the analytical parameters. According to the literature we read, aptasensors using SPCE modified gold nanoparticles with an aptamer immobilization system based on the interaction between streptavidin and biotinylated aptamers, and the optimization of the experiment are the first to be reported. The developed electrochemical aptasensor was tested on saliva samples and also for selectivity against interferences in saliva samples.

\section{Experimental}

\section{Materials}

The materials used in this study were 1-Ethyl-3-(3-dimethyl aminopropyl) carbodiimide (EDC) (Sigma Aldrich, Singapore), 3-mercaptopropionic acid (MPA) (Sigma Aldrich, Singapore), demineralized water (PT Ikapharmindo Putramas, Indonesia), biotinylated aptamer (biotin 5'- CAG CAC CGA CCT TGT GCT TTG GGA GTG CTG GTC CAA GGG CGT TAA TGG ACA-3') (Bioneer, Korea), chloroauric acid $\left(\mathrm{HAuCl}_{4} .3 \mathrm{H}_{2} \mathrm{O}\right.$ ) (synthesized by the Chemical Analysis and Separation Laboratory December 28, 2018, Indonesia), ethanolamine (Merck, Germany), potassium ferricyanide $\mathrm{K}_{3}\left[\mathrm{Fe}(\mathrm{CN})_{6}\right]$ (Sigma Aldrich, Singapore), potassium chloride ( $\mathrm{KCl}$ ) (Merck, Germany), RBD Protein $\mathrm{S}$ SARS-CoV-2 solution (GenScript, USA), trisodium citrate $\left(\mathrm{Na}_{3} \mathrm{C}_{6} \mathrm{H}_{5} \mathrm{O}_{7} .2 \mathrm{H}_{2} \mathrm{O}\right.$ ) (Merck, Germany), Nhydroxysuccinimide (NHS) (Sigma Aldrich, Singapore), phosphate-buffered saline (PBS) pH 7.4 (Merck, Germany), and streptavidin (Promega, USA).

\section{Tools}

The SPCE (GSI Technologies, USA) was used as a working, auxiliary, and $\mathrm{Ag} / \mathrm{AgCl}$ as a reference electrode for the electrochemical transducer. The electrochemistry measurements were conducted using a Zimmer \& Peacock potentiostat connected to a computer using PSTRACE 5.8 software (Zeamer \& Peacock, UK). A scanning electron microscope (SEM) (Hitachi TM3000, Japan) was used for electrode surface morphology analysis. UV-Vis spectrophotometer (Thermo Scientific, US) and Particle Size Analyzer (PSA) (HORIBA SZ-100) were used for the characterization of compounds.

\section{Preparation of colloidal gold nanoparticles (AuNP)}

The gold nanoparticles (AuNP) colloids were prepared by adding $10 \mathrm{~mL}$ of $0.75 \mathrm{mM}$ chloroauric acid, stirring and heating on a magnetic stirrer. After boiling, add as much as $1.7 \mathrm{~mL}$ of $1 \%$ trisodium citrate and stir while heated until the solution color changes to wine red. Then the prepared AuNP colloid was stored in a brown glass bottle at $4{ }^{\circ} \mathrm{C}$. After that, the colloidal gold nanoparticles formed were characterized using a UV-Vis spectrophotometer and a particle size analyzer (PSA) [35,36].

\section{SPCE modification with AuNP}

The overall schematic of the electrochemical aptasensor method is shown in Figure 1. The SPCE surface was rinsed with demineralized water and dried at room temperature. Then, $25 \mu \mathrm{L}$ of colloidal AuNP solution was dropped onto the surface of the SPCE and incubated at room temperature for 24 hours. The SPCE/AuNP was rinsed with demineralized water and dried at room temperature before being electrochemically characterized by differential pulse voltammetry over a 
potential range of -1.0 to $1.0 \mathrm{~V}$ at a scan rate of $0.008 \mathrm{~V} / \mathrm{s}, E_{\text {step }} 0.004 \mathrm{~V}$ with an $E_{\text {pulse }}$ of $0.025 \mathrm{~V}$ and $t_{\text {pulse }}$ of $0.05 \mathrm{~s}$. SPCE before and after modification were also characterized using SEM [37].

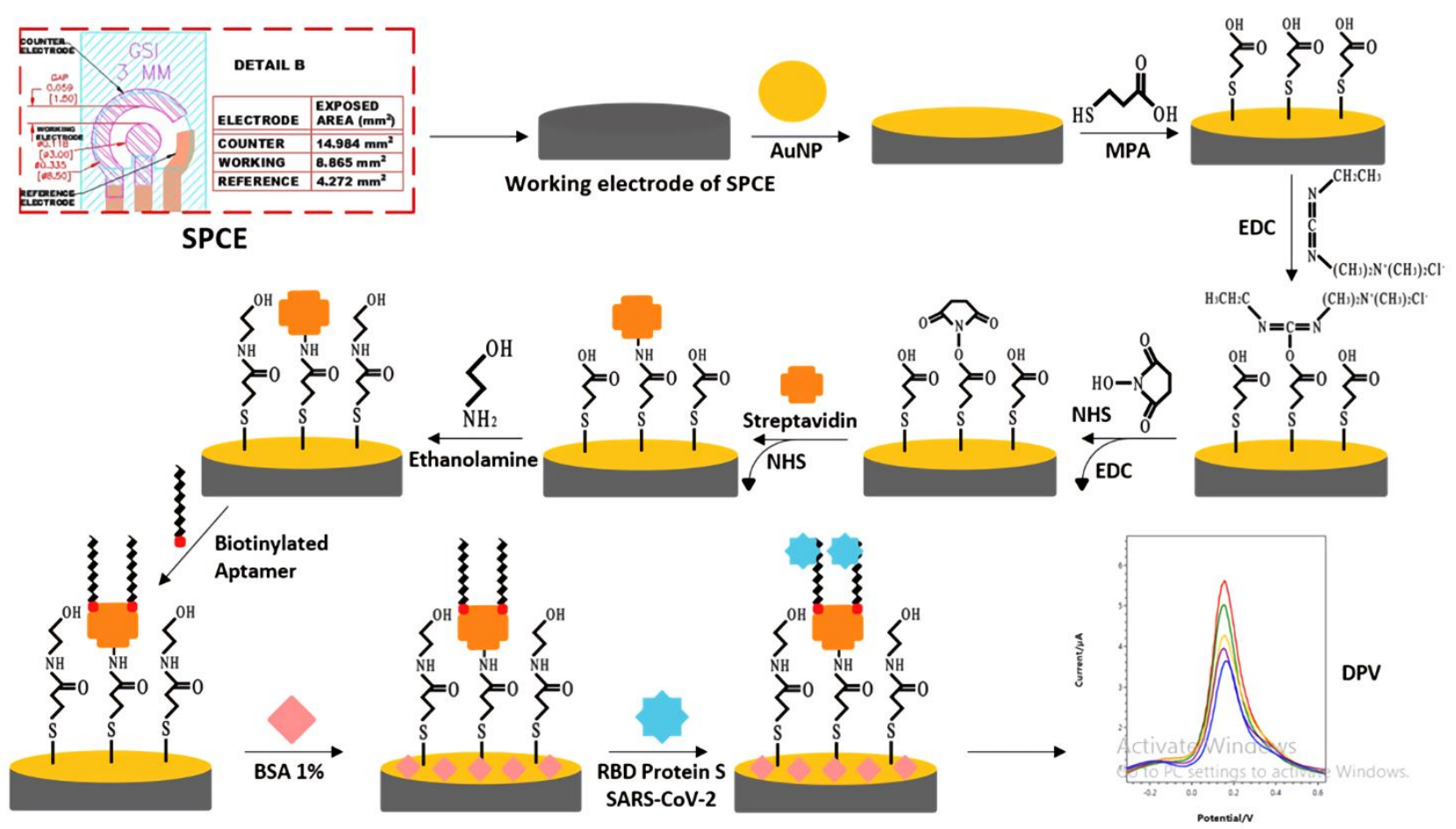

Figure 1. Schematic of an electrochemical aptasensor for RBD Protein S SARS-CoV-2 detection

\section{Fabrication of the electrochemical aptasensor}

The SPCE/AuNP was incubated with $0.01 \mathrm{M} \mathrm{MPA}$ for 20 minutes at $25^{\circ} \mathrm{C}$. After that, the SPCE/ /AuNP/MPA were rinsed with ethanol. Then $0.1 \mathrm{M}$ EDC solution and $0.1 \mathrm{M}$ NHS solution $(1: 1 \mathrm{v} / \mathrm{v})$ were incubated for 60 minutes at $25^{\circ} \mathrm{C}$, and rinsed with demineralized water. The streptavidin solution was incubated overnight at $4{ }^{\circ} \mathrm{C}$ on the surface of the SPCE/AUNP/MPA/EDC:NHS, then rinsed with PBS solution pH $7.40 .01 \mathrm{M}$. Ethanolamine was dropped onto the surface of the SPCE/AuNP/ /MPA/EDC:NHS/Streptavidin for 20 minutes at $25^{\circ} \mathrm{C}$, then rinsed with demineralized water. Furthermore, the $0.5 \mu \mathrm{g} / \mathrm{mL}$ biotinylated aptamer was immobilized on the SPCE/AuNP surface using a streptavidin-biotin system for 40 minutes at $25^{\circ} \mathrm{C}$, then rinsed with PBS solution $\mathrm{pH}$ 7.4 $0.01 \mathrm{M}$.

After the aptamer was successfully immobilized on the surface of the SPCE/AuNP electrode with the streptavidin-biotin system, the non-specific binding site on the electrode surface was incubated using $1 \% \mathrm{BSA}$ solution for 15 minutes at $25^{\circ} \mathrm{C}$, and then rinsed with PBS solution pH 7.4 0.01 M. After that, a solution of RBD protein S SARS-CoV-2 with a certain concentration was dropped on the electrode and incubated for 60 minutes at $25^{\circ} \mathrm{C}$. Then, using a redox system of $10 \mathrm{mM} \mathrm{K} 3\left[\mathrm{Fe}(\mathrm{CN})_{6}\right]$ solution in $0.1 \mathrm{M} \mathrm{KCl}$, differential pulse voltammetry was performed over a potential range of -1.0 to $1.0 \mathrm{~V}$ at a scan rate of $0.008 \mathrm{~V} / \mathrm{s}, E_{\text {step }} 0.004 \mathrm{~V}$ with an $E_{\text {pulse }}$ of $0.025 \mathrm{~V}$ and $t_{\text {pulse }}$ of $0.05 \mathrm{~s}$ [22].

\section{Determination of optimum conditions from parameters affecting experiments}

Factors such as aptamer concentration $\left(X_{1}\right)$, aptamer incubation time $\left(X_{2}\right)$, and incubation time of RBD protein SSARS-CoV-2 $\left(X_{3}\right)$ were selected as factors to be optimized in the experiment $[22,38]$. Each factor is designed at three different levels, the lowest $(-1)$, medium (0), and highest $(+1)$ levels, as shown in Table 1. The response of the measurement results from the experiment was then processed and determined the optimum value of each of these factors using the Box-Behnken experimental design with Minitab18 software. 
Table 1. Optimization factors affecting the experimental conditions

\begin{tabular}{cccc}
\hline Factor & \multicolumn{3}{c}{ Level } \\
\cline { 2 - 4 } & -1 & 0 & +1 \\
\hline Aptamer concentration, $\mu \mathrm{g} / \mathrm{mL}$ & 0.5 & 1.0 & 1.5 \\
\hline Aptamer incubation time, $\mathrm{h}$ & 0.67 & 2 & 16 \\
\hline RBD protein S SARS-CoV-2 incubation time, $\min$ & 30 & 45 & 60 \\
\hline
\end{tabular}

\section{Results and discussion}

\section{Characterization of colloidal gold nanoparticles (AuNP)}

The Turkevich method was first performed in 1951 and is one of the most commonly used methods for the synthesis of gold nanoparticles. It is based on the reduction of the precursor tetrachloroauric acid $\left(\mathrm{HAuCl}_{4}\right)$ with trisodium citrate in a boiling water solution. Figure 2a shows the results of UV-Vis spectrophotometry of gold nanoparticles with a peak at $521 \mathrm{~nm}$. However, Figure $2 \mathrm{~b}$ shows the results of the particle size analyzer (PSA) characterization that the gold nanoparticles formed are $38.6 \mathrm{~nm}$ in size.

The oxidation number of gold includes $\mathrm{Au}^{+1}$ (aurous), $\mathrm{Au}^{+3}$ (auric/aurat), and the one that is not oxidized is $\mathrm{Au}^{0} . \mathrm{Au}^{0}$ is the final condition required for a nanoparticle. Therefore, the basic principle of this method involves the reduction of $\mathrm{Au}^{3+}$ to $\mathrm{Au}^{0}$ in the presence of a reducing agent such as trisodium citrate. The precursor chosen is chloroauric acid $\left(\mathrm{HAuCl}_{4}\right)$, where gold is in the oxidation state $\mathrm{Au}^{+3}$ [39-41], while trisodium citrate functions as a stabilizing and reducing agent. Trisodium citrate electrostatically stabilizes gold nanoparticles. Because of the repulsion between the negative charges on the surface, the negative charge of the citrate ion adsorbed on the surface of the gold nanoparticles can prevent aggregation between nanoparticles [42,43].

a

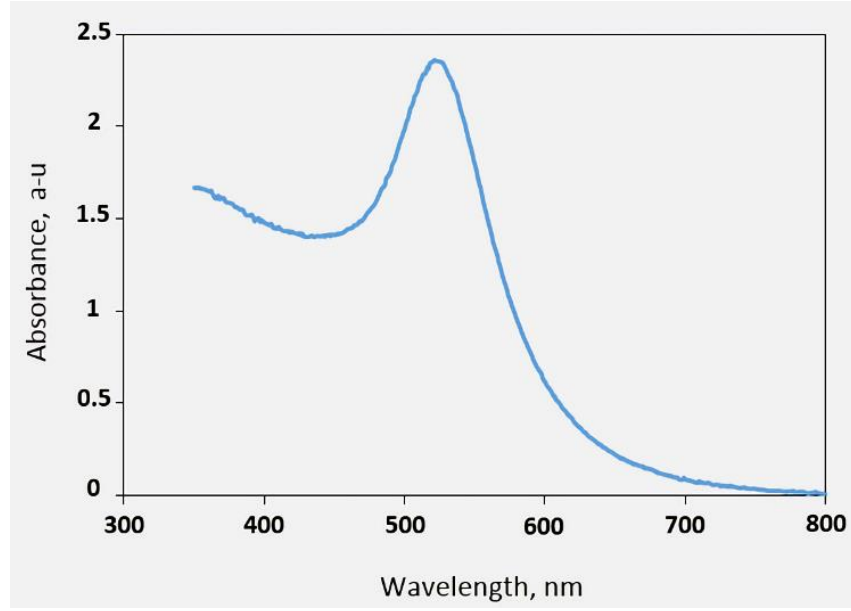

b

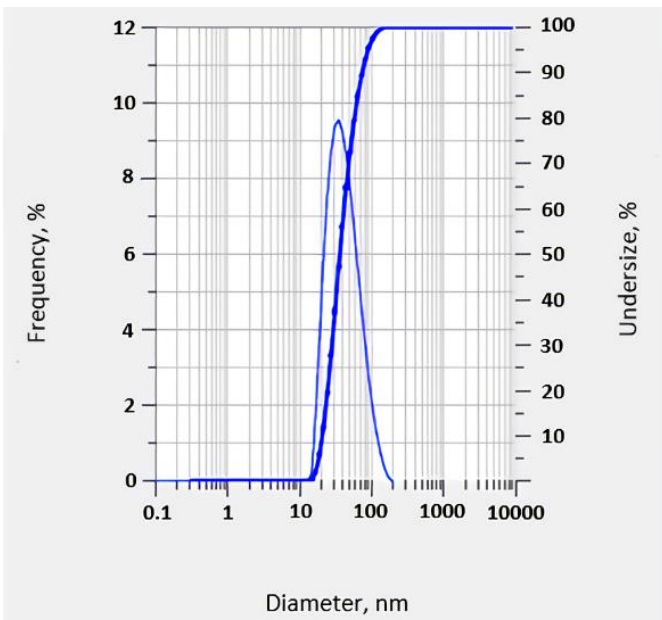

Figure 2. Characterization of gold nanoparticles. (a) The results of the characterization of gold nanoparticles using a UV-VIS spectrophotometer. The maximum absorption wavelength of gold nanoparticles is at $521 \mathrm{~nm}$;

(b) Characterization results of Particle Size Analyzer (PSA) of gold nanoparticles with a size of $38.3 \mathrm{~nm}$

The use of nanoparticles is one of the methods used in the development of a biosensor. The function of nanoparticles in biosensors is to increase the immobilization of biomolecules, catalyze electrochemical reactions, label molecules, and enhance electron transfer. Several types of nanoparticles are used in biosensor applications, one of which is gold nanoparticles. Gold nanoparticles have a suitable function for increasing the sensitivity and selectivity of biosensors because of their 
relatively simple biocompatibility, optical, electronic, production, and modification properties [40], and also exhibit a high surface area ratio and excellent conductivity [44].

The characterization of gold nanoparticles aims to determine the distribution of particle size and morphology because these two parameters are very important in the characterization of a nanoparticle. The UV-Vis spectrophotometer is one of the important instruments used for the characterization of synthesized nanoparticles. The interaction of gold nanoparticles with light can be determined by the size, morphology, shape, and chemical environment of the synthesized nanoparticles. The resonance resulting from the electron oscillation of gold nanoparticles and incident light waves provides surface plasmon resonance of gold nanoparticles. The surface plasmon resonance for gold nanoparticles is in the wavelength range of 500-600 nm, depending on the particle size [45]. The AuNP colloid produced in this study has an absorption peak at a maximum wavelength of $521 \mathrm{~nm}$, which indicates that the size of the gold nanoparticles produced is quite good. Figure 2a shows the absorption of gold nanoparticles at $521 \mathrm{~nm}$.

Gold nanoparticles were assessed using a particle size analyzer (PSA) and the dynamic light scattering (DLS) technique, which shows the average diameter of hydrodynamic particles in a liquid solution. Figure $2 \mathrm{~b}$ shows the DLS analysis of gold nanoparticles with an average size of $38.3 \mathrm{~nm}$.

\section{Characterization of electrochemical aptasensor}

One of the working electrodes often used is the screen printed-carbon electrode (SPCE). SPCE has many advantages, such as high efficiency, ease of carrying and use, fast analysis, and small sample size, so it is very prospective for sensor development [46]. The use of gold nanoparticles in SPCE can increase the electroactive surface area and increase electron transfer rate between the electrode and the analyte. The modified electrodes provide fast, accurate measurements, as well as high sensitivity and selectivity [47].

SPCE before and after modification with gold nanoparticles was characterized using differential pulse voltammetry in $10 \mathrm{mM} \mathrm{K}_{3}\left[\mathrm{Fe}(\mathrm{CN})_{6}\right]$ solution in $0.1 \mathrm{M} \mathrm{KCl}$. The redox system of $\mathrm{K}_{3}\left[\mathrm{Fe}(\mathrm{CN})_{6}\right]$ solution at bare SPCE (curve a) and SPCE/AuNP (curve b) showed an increase in peak current response after SPCE was modified with gold nanoparticles, as shown in Figure 3a. This is due to an increase in the conductivity of gold nanoparticles in SPCE/AuNP by increasing electron transfer between the electrode and analyte, compared to bare SPCE.

To test the electrode changes before and after the modification process, a $\mathrm{K}_{3}\left[\mathrm{Fe}(\mathrm{CN})_{6}\right]$ solution was used as a mediator. The reduction and oxidation reactions that occur in $\mathrm{K}_{3}\left[\mathrm{Fe}(\mathrm{CN})_{6}\right]$ are as shown in equation (1) [48].

$$
\left[\mathrm{Fe}(\mathrm{CN})_{6}\right]^{3-}+\mathrm{e}^{-} \leftrightarrows\left[\mathrm{Fe}(\mathrm{CN})_{6}\right]^{4-}
$$

As a bioreceptor in this research, the DNA aptamer developed by Song et al. [5], named CoV2-RBD-1C, which can recognize the RBD protein S SARS-CoV-2, was used in this study because of the binding interaction between the RBD protein S SARS-CoV-2 and the aptamer involved, previously characterized by molecular dynamics (MD) techniques. More specifically, the aptamer can interact with the RBD protein S SARS-CoV-2 through hydrogen bond formation, the CoV2-RBD$1 C$ aptamer forming hydrogen bonds with Threonin500, Glutamine506, and Asparagine437 of the RBD protein S SARS-CoV-2. Moreover, the aptamer has been selected in the working buffer under physiological conditions, therefore, it can support the measurement of protein $\mathrm{S}$ in biological fluids. As for the approximate dissociation constant (KD) of the aptamer, it is $5.8 \pm 0.8 \mathrm{nM}$, which is comparable to commercially available antibodies developed to bind to protein $\mathrm{S}$. The selected 
aptamers are ideal recognition probes for RBD protein S SARS-CoV-2 because of their high affinity, small size, and ease of modification and use [5].

a

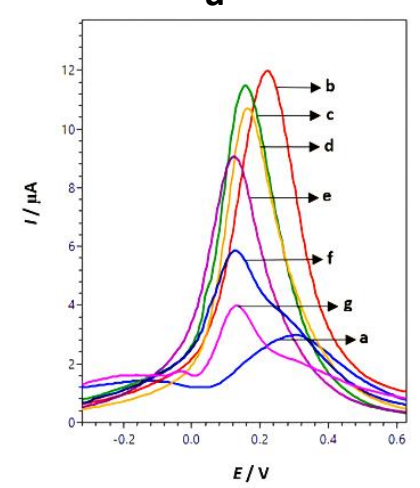

C

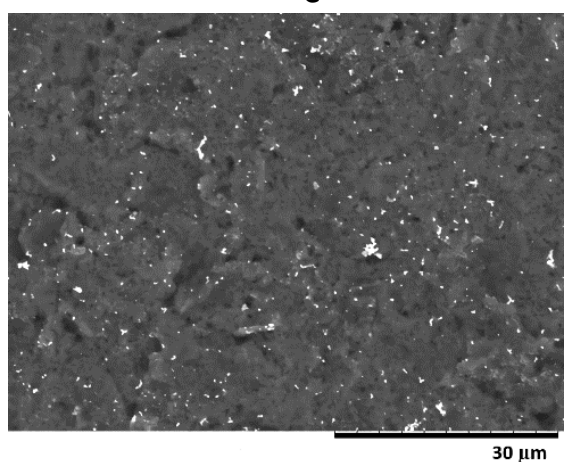

b

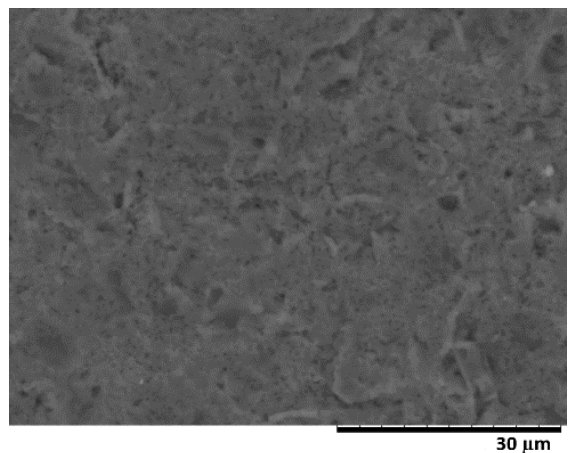

d

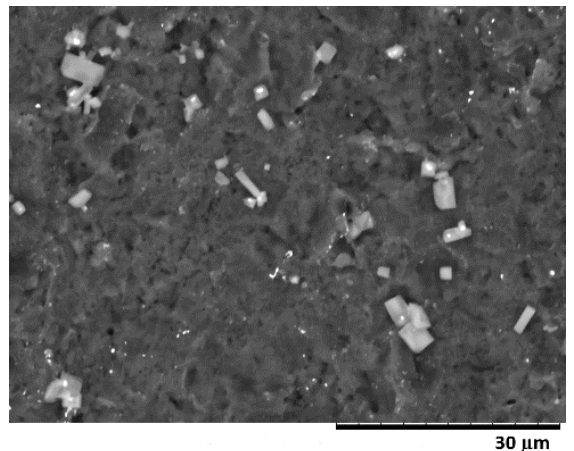

Figure 3. (a) Differential pulse voltammogram characterized using a redox system solution of $K_{3}\left[\mathrm{Fe}(\mathrm{CN})_{6}\right]$ solution $10 \mathrm{mM}$ in $0.1 \mathrm{M} \mathrm{KCl}$; SPCE characterization using SEM (b) bare SPCE, (c) SPCE/AUNP, and (d) SPCE/AuNP/Streptavidin/Aptamer

Aptamer immobilization on the SPCE/AuNP surface was carried out with the streptavidin-biotin system. As for the immobilization of streptavidin on the surface of SPCE/AuNP, it is based on direct covalent bonds on the surface of the transducer that functions on the gold surface through the alkanethiol group, namely MPA (3-mercaptopropionic acid). MPA is an organosulfur compound that can bind to gold through Au-S bonds. The other terminal end of MPA is the carboxylate group, so the carboxyl group can chemically bind to other groups. The strong affinity for sulfur atoms to the surface of gold due to the interaction of sulfur-gold atoms is $188.28 \mathrm{~J} / \mathrm{mol}$, so it can form stable covalent bonds [30].

The modified carboxylate group on the SPCE/AuNP surface was then activated with a solution of EDC:NHS to form a reactive succinamide ester. This reactive group can bind to the primary amine group of streptavidin covalently on the surface of SPCE/AuNP. After the addition of streptavidin, SPCE/AuNP/MPA/EDC:NHS/Streptavidin were formed. The addition of ethanolamine is needed to avoid non-specific bonding on the electrode surface that has been immobilized by streptavidin. The $\mathrm{COOH}$ group on the electrode surface that is not bound to streptavidin will be blocked with ethanolamine so that the immobilized streptavidin on the surface of the aptasensor has a good orientation.

After that, the biotinylated aptamer was incubated on the surface of the electrode and then

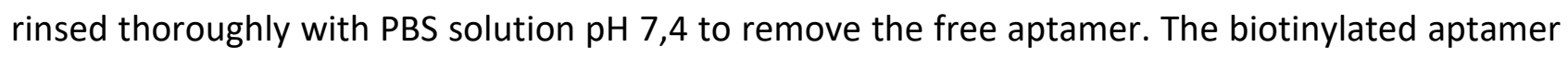
binds to streptavidin by non-covalent interaction.

To determine whether the biotinylated aptamer was successfully formed on the surface of the electrode, differential pulse voltammetry was used with a redox system of $\mathrm{K}_{3}\left[\mathrm{Fe}(\mathrm{CN})_{6}\right]$ solution $10 \mathrm{mM}$ 
in $0.1 \mathrm{M} \mathrm{KCl}$ over a potential range of -1.0 to $1.0 \mathrm{~V}$ at a scan rate of $0.008 \mathrm{~V} / \mathrm{s}, E_{\text {step }} 0.004 \mathrm{~V}$ with an $E_{\text {pulse }}$ of $0.025 \mathrm{~V}$ and $t_{\text {pulse }}$ of $0.05 \mathrm{~s}$. In Figure $3 a$ shows the highest peak current increase occurred when SPCE was modified with gold nanoparticles (curve b), then decreased gradually after the addition of MPA (curve c), the addition of MPA/EDC:NHS (curve d), the addition of MPA/ /EDC:NHS/Streptavidin (curve e), and the addition of MPA/ EDC:NHS/ Streptavidin/Aptamer (curve f). The current decreases for the first time when MPA (curve $c$ ) is added to the surface of the SPCE/AuNP electrode, forming SPCE/AuNP/MPA because MPA has been immobilized on the surface of SPCE/AuNP through covalent bonds, allowing electron transfer between electroactive species in solution $\mathrm{K}_{3}\left[\mathrm{Fe}(\mathrm{CN})_{6}\right]$ and the electrode is blocked due to the density present on the electrode surface after chemisorption between MPA and gold nanoparticle. The current decrease occurred again when the addition of EDC:NHS (curve d) activated the MPA carboxylate group by forming a reactive succinamide ester on the surface of SPCE/AuNP to form SPCE/AuNP/MPA/ /EDC:NHS. EDC:NHS was also used as a facilitator to covalently mobilize streptavidin on the surface of SPCE/AuNP containing carboxylic groups. The decrease in current indicates that the immobilization of these compounds was successful, as the transfer of electrons between electroactive species solution $\mathrm{K}_{3}\left[\mathrm{Fe}(\mathrm{CN})_{6}\right]$ and the electrode is blocked as the electroactive species solution $\mathrm{K}_{3}\left[\mathrm{Fe}(\mathrm{CN})_{6}\right]$ moves away from the electrode surface. The addition of streptavidin then also causes a decrease in the current (curve e). Because streptavidin is a nonelectroactive macromolecule, it can prevent electron transfer from $\mathrm{K}_{3}\left[\mathrm{Fe}(\mathrm{CN})_{6}\right]$ solution. At the time of immobilization of the biotinylated aptamer (curve $f$ ) there was also a decrease in current because the electrode surface was getting denser. This indicates that the immobilization was successful, as the flow of solution $\mathrm{K}_{3}\left[\mathrm{Fe}(\mathrm{CN})_{6}\right]$ will be lower, causing the $\left[\mathrm{Fe}(\mathrm{CN})_{6}\right]^{3-/ 4}$-species to be further away from the electrode surface due to electron transfer being hampered by a decrease in the conductivity of the AuNP-modified electrode.

A morphology analysis with SEM was carried out to determine the success of the modification of the working electrode, which could be seen from its morphology. Figure $3 b, c$, and $d$ show the bare SPCE, SPCE/AuNP, and SPCE/AuNP/Streptavidin/Aptamer surfaces. Figure $3 c$ shows that the SPCE surface is smoother and more homogeneous than after being modified with AuNP (Figure 3c). This indicates that the modification process has been successfully carried out. Figure $3 d$, on the other hand, displays a rougher electrode surface, showing that streptavidin and aptamer have been successfully immobilized on the electrode surface.

The biotinylated aptamer that had been immobilized was incubated with a $1 \%$ BSA solution to cover the active site on the surface of the electrode. The BSA molecule will fill the small gaps in the empty areas on the electrodes. The goal is that the measurement does not produce a current that can interfere with the analysis results of the analyte. To detect RBD protein S SARS-CoV-2, the protein standard solution in PBS pH 7.4 was incubated on the electrode surface. After that, the electrodes were rinsed with PBS solution $\mathrm{pH} 7.4$ to eliminate molecules that did not bind to the biotinylated aptamer, such as RBD protein S SARS-CoV-2.

To determine whether RBD protein S SARS-CoV-2 has been immobilized on the electrode surface, differential pulse voltammetry is used to observe the redox system of $K_{3}\left[\mathrm{Fe}(\mathrm{CN})_{6}\right]$ solution over a potential range of -1.0 to $1.0 \mathrm{~V}$ at a scan rate of $0.008 \mathrm{~V} / \mathrm{s}, E_{\text {step }} 0.004 \mathrm{~V}$ with an $E_{\text {pulse }}$ of $0.025 \mathrm{~V}$ and $t_{\text {pulse }}$ of $0.05 \mathrm{~s}$. The attachment of RBD protein S to SARS-CoV-2 to the biotinylated aptamer causes a decrease in the peak of the $\mathrm{K}_{3}\left[\mathrm{Fe}(\mathrm{CN})_{6}\right]$ current, as shown in Figure 3a (curve g). This is because the RBD protein S SARS-CoV-2 is a large biomolecule that is not electroactive, so it can block the electron transfer process on the surface of the electrode. The measured current response will be inversely proportional to the number of non-electroactive biomolecules involved. Because the more 
RBD protein S SARS-CoV-2 is attached to the surface of the electrode, the more it blocks the electron transfer process from the redox system of $\mathrm{K}_{3}\left[\mathrm{Fe}(\mathrm{CN})_{6}\right]$ solution, the higher the concentration of RBD protein S SARS-CoV-2, the lower the current response. On the other hand, the lower the concentration of RBD protein S SARS-CoV-2, the higher the current response.

\section{The optimal experimental conditions}

Three factors, such as aptamer concentration $\left(X_{1}\right)$, aptamer incubation time $\left(X_{2}\right)$, and incubation time of RBD protein S SARS-CoV-2 $\left(X_{3}\right)$, were selected as factors to be optimized in the experiment. The effect of aptamer concentration, aptamer incubation time, and RBD protein S SARS-CoV- 2 incubation time on the current response of the aptasensor was tested using differential pulse voltammetry with a redox system of $10 \mathrm{mM} \mathrm{K}_{3}\left[\mathrm{Fe}(\mathrm{CN})_{6}\right]$ solution in $0.1 \mathrm{M} \mathrm{KCl}$ over a potential range of -1.0 to $1.0 \mathrm{~V}$ at a scan rate of $0.008 \mathrm{~V} / \mathrm{s}, E_{\text {step }} 0.004 \mathrm{~V}$ with an $E_{\text {pulse }}$ of $0.025 \mathrm{~V}$ and $t_{\text {pulse }}$ of $0.05 \mathrm{~s}$.

In SPCE/AUNP/MPA/EDC:NHS/Streptavidin, aptamer was dripped with various concentrations of $0.5,1.0$, and $1.5 \mu \mathrm{g} / \mathrm{mL}$ and was incubated with time variations of $0.67,2$, and 16 hours at $25{ }^{\circ} \mathrm{C}$. While RBD protein S SARS-CoV-2 incubated with time variations of 30,45 , and 60 minutes at $25{ }^{\circ} \mathrm{C}$.

The optimum value of each factor was determined using the Box-Behnken experimental design with the Minitab 18 program. The relationship between the response and the factors was determined through a sequence of experiments to obtain the optimum response results, and each factor was designed through 3 levels, namely, the lowest level (-1), medium level (0), and the highest level $(+1)$, as observed in Table 1. Experiments using 3 factors with 3 different levels were carried out 15 times, so that there were 15 trials. The response of the measurement results from the suggested experiment is then processed with the Minitab 18 program so that it can predict the maximum current value. From the experimental data obtained, the following regression equation (2) was found:

$$
\begin{aligned}
Y= & -3.00+3.40 X_{1}+0.237 X_{2}-0.1598 X_{3}-2.265 X_{1} X_{1}-0.01172 X_{2} X_{2}- \\
& -0.002109 X_{3} X_{3}-0.0112 X_{1} X_{2}+0.0214 X_{1} X_{3}+0.000891 X_{2} X_{3}
\end{aligned}
$$

As shown in Eq. (2), if the response coefficient was positive, the presence of these factors would increase the current response. A negative coefficient indicated that the presence of these factors would decrease the current response. From the analysis of the current response obtained from the differential pulse voltammetry, we obtained the ANOVA results presented in Table 2, which explain the variability of the data. The $p$-value data for each factor was obtained from the ANOVA. A model that is in accordance with the linear model is indicated by a $p$-value of less than 0.05 , which implies that a single variable showed a linear effect. The interaction effect is shown from a combination of two variables, and to determine the significance of each variable, the $p$-value was used. The independent variable, which had no significant effect, is indicated by a p-value of more than 0.05 . In addition, based on the ANOVA results from the Box-Behnken experimental design, Table 2 shows the $p$-value of each factor, namely $X_{1}=0.189 ; X_{2}=0.001$; and $X_{3}=0.874$. The factor is considered significant if the $p$-value $<0.05$. It can be seen that the incubation time factor of the aptamer has a significant effect on the experimental results.

Response optimization helps you identify the combination of variable settings that jointly optimize a single response or a set of responses. This is useful when you need to evaluate the impact of multiple variables on a response. Response optimization is most effective when interpreted in conjunction with relevant subject matter expertise, including background information, theoretical principles, and knowledge obtained through observation or previous experimentation. When optimizing responses, you must specify whether your goal is to minimize, maximize, or meet a target response. In this research, we use minimize, so the response when the optimum response is low. The performance of all design 
and response variables is shown in Figure 4, where the best optimization approaches an overall optimum operating condition of aptamer concentration at $0.5 \mu \mathrm{g} / \mathrm{mL}$, aptamer incubation time at 40 minutes ( 0.67 hours), and RBD protein S SARS-CoV- 2 incubation time at 60 minutes. Thus, when the experimental conditions proposed by Minitab are applied to our experimentation, the values of the responses obtained are almost equal to the values obtained by calculating.

Tabel 2. Analysis of variance

\begin{tabular}{cccccc}
\hline Source & DF & Adj SS & Adj MS & F-value & $p$-value \\
\hline Model & 9 & 4.88120 & 0.54236 & 11.43 & 0.008 \\
\hline Linear & 3 & 2.65810 & 0.88603 & 18.67 & 0.004 \\
\hline$X_{1}$ & 1 & 0.10954 & 0.10954 & 2,1 & 0.189 \\
\hline$X_{2}$ & 1 & 2.54723 & 2.54723 & 5.68 & 0.001 \\
\hline$X_{3}$ & 1 & 0.00133 & 0.00133 & 0.03 & 0.874 \\
\hline Square & 3 & 1.93177 & 0.64392 & 13.57 & 0.008 \\
\hline$X_{1} X_{1}$ & 1 & 1.18355 & 1.18355 & 24.94 & 0.004 \\
\hline$X_{2} X_{2}$ & 1 & 0.13378 & 0.13378 & 2.82 & 0.154 \\
\hline$X_{3} X_{3}$ & 1 & 0.83103 & 0.83103 & 17.51 & 0.009 \\
\hline 2-Way Interaction & 3 & 0.16966 & 0.05655 & 1.19 & 0.402 \\
\hline$X_{1} X_{2}$ & 1 & 0.00996 & 0.00996 & 0.21 & 0.666 \\
\hline$X_{1} X_{3}$ & 1 & 0.10336 & 0.10336 & 2.18 & 0.200 \\
\hline$X_{2} X_{3}$ & 1 & 0.05634 & 0.05634 & 1.19 & 0.326 \\
\hline Error & 5 & 0.23726 & 0.04745 & & \\
\hline Lack-of-Fit & 3 & 0.05122 & 0.01707 & 0.18 & 0.900 \\
\hline Pure Error & 2 & 0.18603 & 0.09302 & & \\
\hline Total & 14 & 5.11845 & & & \\
\hline
\end{tabular}

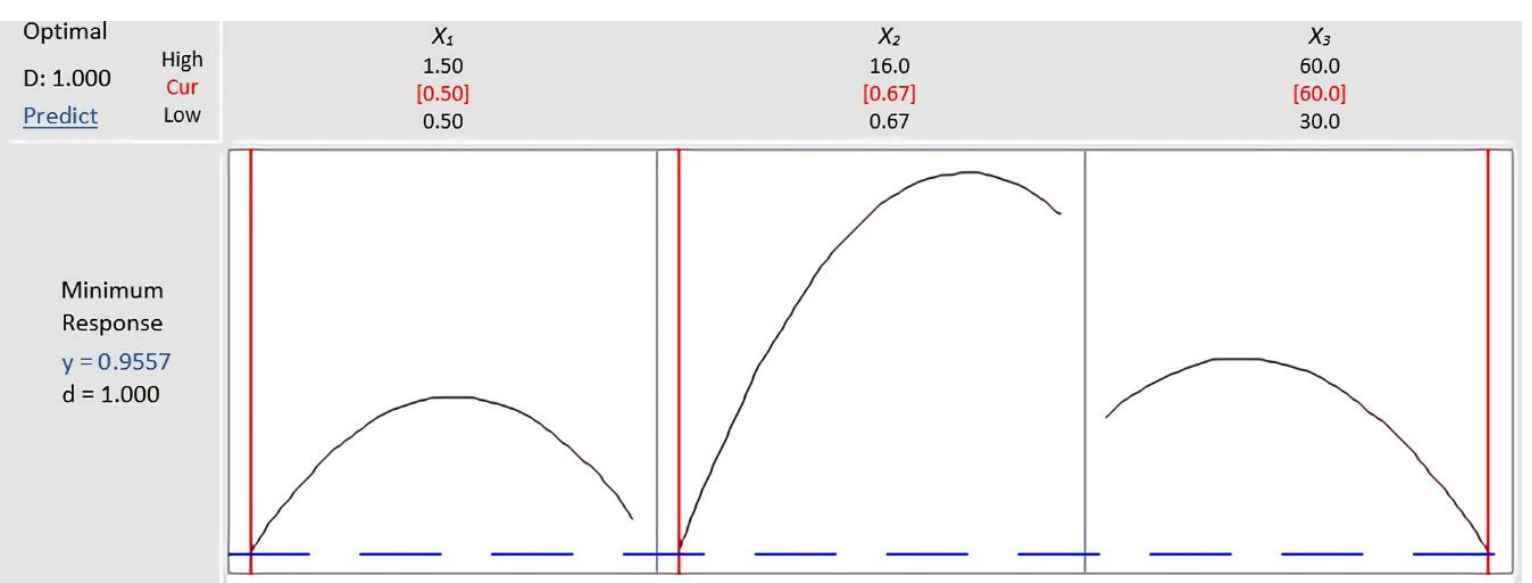

Figure 4. Response optimization of the optimal experimental conditions

\section{Electrochemical aptasensor performance}

After knowing the optimum conditions of several parameters that affect the experiment, a calibration curve is made and the detection limit of the aptasensor is calculated using variations in the concentration of RBD protein SSARS-CoV-2. Variations in the concentration of RBD protein SSARS-CoV-2 used are: 50; 40; 30; 20; $10 \mathrm{ng} / \mathrm{mL}$. The aptasensor was characterized electrochemically by a redox system of $\mathrm{K}_{3}\left[\mathrm{Fe}(\mathrm{CN})_{6}\right]$ solution using differential pulse voltammetry over a potential range of -1.0 to $1.0 \mathrm{~V}$ at a scan rate of $0.008 \mathrm{~V} / \mathrm{s}, E_{\text {step }} 0.004 \mathrm{~V}$ with an $E_{\text {pulse }}$ of $0.025 \mathrm{~V}$ and $t_{\text {pulse }}$ of $0.05 \mathrm{~s}$. The electrochemical response was measured using differential pulse voltammetry, as shown in Figure $5 \mathrm{a}$.

The voltammogram shows that the higher the concentration of RBD protein S SARS-CoV-2, the lower the current response. This is because the RBD protein S SARS-CoV-2 is a large biomolecule 
that is not electroactive, so the more RBD protein S SARS-CoV-2 binds to the aptamer, the electrode surface becomes denser and this causes the electron transfer process on the electrode surface to be hindered.

a

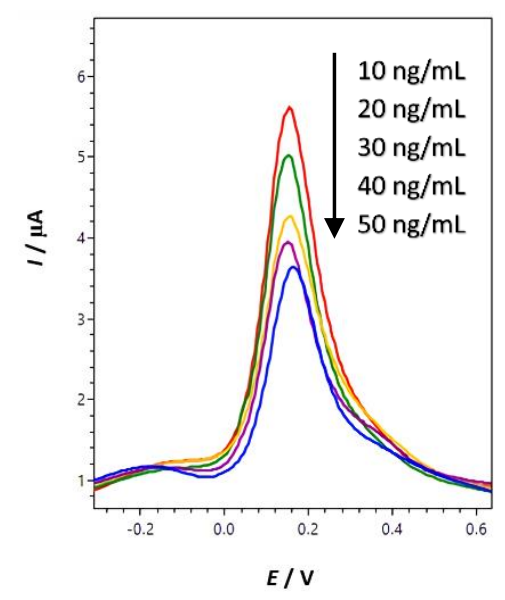

b

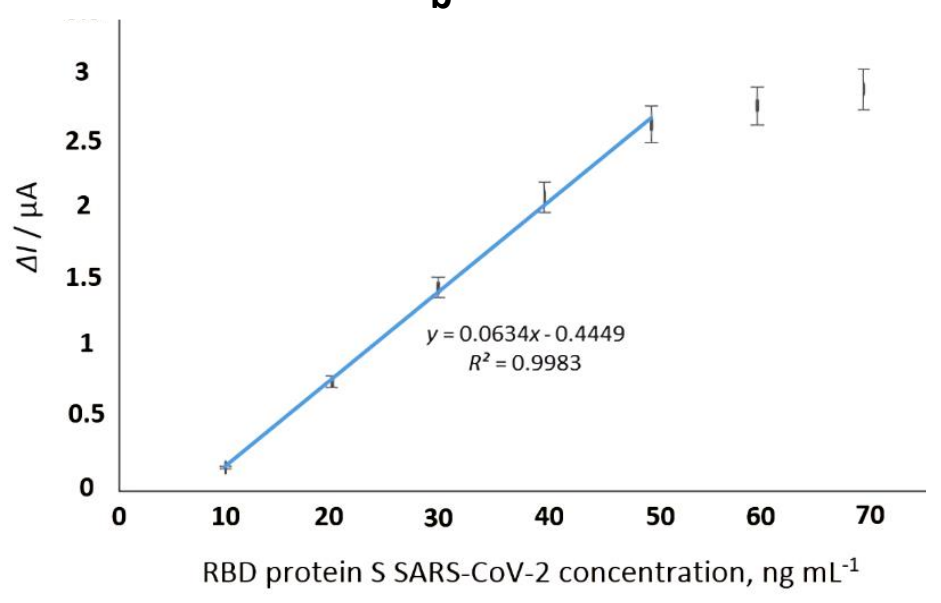

Figure 5. (a) Differential pulse voltammogram determining the concentration of RBD Protein S SARS-CoV-2 (10; 20; 30; 40; $50 \mathrm{ng} / \mathrm{mL})$ using a redox system of $10 \mathrm{mM} K_{3}\left[\mathrm{Fe}(\mathrm{CN})_{6}\right]$ solution in $0.1 \mathrm{M} \mathrm{KCl}$; (b)

Electrochemical aptasensor calibration curve for detection of RBD Protein S SARS-CoV-2

Then the resulting current response is plotted into a calibration curve for various concentrations of RBD protein S SARS-CoV-2 $(50 ; 40 ; 30 ; 20 ; 10 \mathrm{ng} / \mathrm{mL})$ to create a calibration curve as shown in Figure $5 b$, so that a linear regression equation is obtained with $y=0.0634 x-0.4449$ with $R^{2}=0.9983$. The detection limit obtained is $2.63 \mathrm{ng} / \mathrm{mL}$ and the quantification limit is $7.97 \mathrm{ng} / \mathrm{mL}$.

The detection limit obtained in this study is quite low, as can be seen in Table 3. The detection limit in this study is higher when compared to Abrego-Martinez et al. [21] study of an aptamer-based biosensor developed on a screen-printed carbon electrode modified with gold nanoparticles for SARS-CoV-2 detection.

Table 3. Electrochemical biosensor studies to detect SARS-CoV-2

\begin{tabular}{ccc}
\hline Method & Limit of detection, ng/mL & Ref. \\
\hline $\begin{array}{c}\text { Two-dimensional (2D) metal-organic framework (MOF)-based } \\
\text { photoelectrochemical (PEC) aptasensor for SARS-CoV 2 spike } \\
\text { glycoprotein (S protein) detection }\end{array}$ & 72 & {$[49]$} \\
\hline $\begin{array}{c}\text { Electrochemical aptasensor to detect SARS-CoV-2 protein S RBD as a } \\
\text { biomarker of COVID-19 disease using a screen printed carbon } \\
\text { electrode/AuNP }\end{array}$ & 2.63 & $\begin{array}{c}\text { This } \\
\text { research }\end{array}$ \\
\hline $\begin{array}{c}\text { Electrochemical aptasensor using screen printed carbon } \\
\text { electrode/AuNP for SARS-CoV-2 spike (S) protein detection }\end{array}$ & - & {$[20]$} \\
\hline $\begin{array}{c}\text { Electrochemical aptasensor using screen printed carbon } \\
\text { electrode/AuNP targeting the receptor-binding domain (RBD) in the } \\
\text { spike protein (S-protein) of the SARS-CoV-2 }\end{array}$ & 0.066 & {$[21]$} \\
\hline $\begin{array}{c}\text { Electrochemical dual-aptamer biosensor based on the metal-organic } \\
\text { frameworks MIL-53(Al) decorated with Au@Pt nanoparticles and } \\
\text { enzymes to determine SARS-CoV-2 nucleocapsid protein }\end{array}$ & & [50] \\
$\begin{array}{c}\text { (2019-nCoV-NP) via co-catalysis of the nanomaterials, horseradish } \\
\text { peroxidase (HRP) and G-quadruplex DNAzyme }\end{array}$ & & 0.00833 \\
\hline
\end{tabular}

The aptasensor relies on an aptamer targeting the receptor-binding domain (RBD) in the spike protein (S-protein) of the SARS-CoV-2. But the detection limit in this study is lower when compared 
to the Jiang et al. [49] study about a two-dimensional (2D) metal-organic framework (MOF)-based photoelectrochemical (PEC) aptasensor with high sensitivity and stability for SARS-CoV-2 spike glycoprotein (S protein) detection. This proves that the electrochemical aptasensor method using SPCE modified gold nanoparticles developed in this study can be used for the detection of COVID-19 disease using the RBD protein S SARS-CoV-2 as a biomarker.

\section{Selectivity and stability of the aptasensor}

A method's selectivity refers to its ability to test just particular analytes in the presence of other components in the sample matrix [51-53]. Although the presence of aptamers as bioreceptors provides sensitivity to target analytes, the aptasensors to be developed must also have good interference rejection characteristics in order to be useful in real sample analysis. Saliva has an important role in diagnostics as it provides a convenient and cost-effective Point of Care Technology (POCT) platform for rapid detection [54]. Liv. [55] investigated the effect of several enzymes, compounds, and ions found in saliva on electrochemical immunosensors used to detect SARS-CoV-2 antibodies, including $\alpha$-amilase, lipase, $\mathrm{Na}^{+}, \mathrm{K}^{+}, \mathrm{Ca}^{2+}, \mathrm{Mg}^{2+}, \mathrm{H}_{2} \mathrm{PO}_{4}{ }^{-}, \mathrm{HPO}_{4}{ }^{2-}$, urea, $\mathrm{HCO}_{3}{ }^{-}$, and $\mathrm{NH}_{3}$ [55].

a

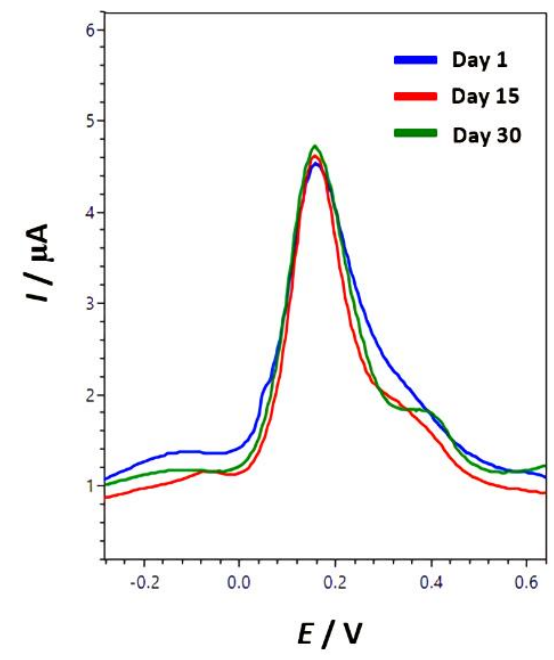

b

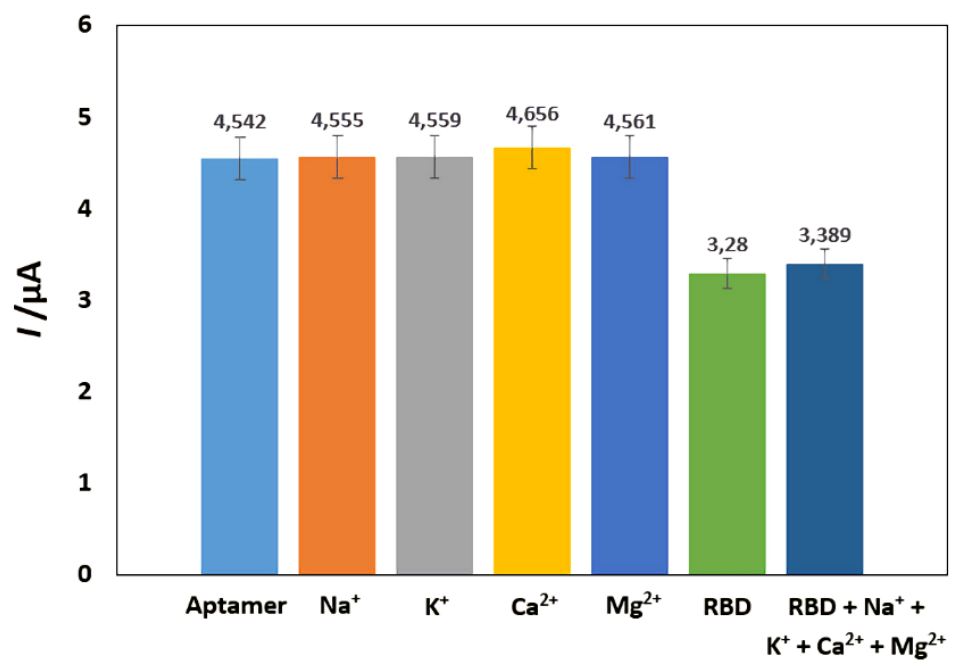

Figure 6. (a) $\mathrm{Na}^{+}, \mathrm{K}^{+}, \mathrm{Ca}^{2+}$, and $\mathrm{Mg}^{2+}$ ion selectivity of the aptasensor; (b) Differential pulse voltammogram response obtained with $30 \mathrm{ng} / \mathrm{mL}$ RBD protein S SARS-CoV-2 to evaluate the stability of the aptasensor after

1 month of storage in an oven at $50^{\circ} \mathrm{C}$ using a redox system of $10 \mathrm{mM} \mathrm{K} K_{3}\left[\mathrm{Fe}(\mathrm{CN})_{6}\right]$ solution in $0.1 \mathrm{M} \mathrm{KCl}$

Selectivity was determined for $\mathrm{Na}^{+}, \mathrm{K}^{+}, \mathrm{Ca}^{2+}$, and $\mathrm{Mg}^{2+}$ ions. The measured current peak response was compared with the RBD protein S SARS-CoV-2 peak response at a concentration of $100 \mathrm{ng} / \mathrm{mL}$. Figure 6a shows the current responses of $\mathrm{Na}^{+}, \mathrm{K}^{+}, \mathrm{Ca}^{2+}$, and $\mathrm{Mg}^{2+}$ ions, which are not much different from the aptamer as a negative control. This indicates that there is no binding between the aptamer and $\mathrm{Na}^{+}, \mathrm{K}^{+}, \mathrm{Ca}^{2+}$, and $\mathrm{Mg}^{2+}$ ions. Other treatments were studied to see the effect of interference in determining the percentage of selectivity. As shown in Figure $6 \mathrm{a}$, the addition of an interference that is a mixture of $\mathrm{Na}^{+}, \mathrm{K}^{+}, \mathrm{Ca}^{2+}$, and $\mathrm{Mg}^{2+}$ ions in the RBD protein S SARS-CoV-2 showed a measurable response peak of $3,389 \mu \mathrm{A}$, which was not significantly different from the peak response for the RBD protein S SARS-CoV-2, which was 3,280 $\mu \mathrm{A}$. This means that the aptamer activity is very good at recognizing the RBD protein S SARS-CoV-2 as the target analyte. The presence of interference did not affect the activity of the aptamer against RBD protein S SARS-CoV-2. Aptamer selectively recognized only RBD protein S SARS-CoV-2 as the target analyte in a matrix containing $\mathrm{Na}^{+}, \mathrm{K}^{+}, \mathrm{Ca}^{2+}$, and $\mathrm{Mg}^{2+}$ ions, which neither interfered with nor bound to the aptamer, and obtained a selectivity value of $91.36 \%$. 
The screen-printed carbon electrodes that are used in this aptasensor are disposable devices specially designed to work with microvolumes of sample. Ideal for quality control or research purposes, and also for teaching electrochemistry. Biosensors are sensitive to aging, which is defined as a decline in signal over time. Biosensor aging is defined as a loss of signal at a specific concentration of the measured analyte. Time, handling or manner of usage, and temperature all have a role in aging. Shelf-life studies are frequently carried out, but they are rarely published. For single-use disposable sensors, such investigations are sufficient, but they reveal little about aging characteristics for long-term usage [56]. The term "stability" refers to the variance in detection signals during the course of long-term storage [57]. To assess the stability of the aptasensor, the current response to $30 \mathrm{ng} / \mathrm{mL}$ RBD protein S SARS-CoV-2 was recorded after 1 month of storage in an oven at $50{ }^{\circ} \mathrm{C}$. The differential pulse voltammogram response shown in Figure $6 \mathrm{~b}$ revealed that the response increased after periodic measurements of 1 day (curve a; $3.503 \mu \mathrm{A}$ ), 15 days (curve b; $3.532 \mu \mathrm{A}$ ), and 30 days (curve c; $3.565 \mu \mathrm{A}$ ), representing a loss of sensory activity, but not significantly different. These findings suggest that the aptasensor is relatively stable, which could indicate the suggested platform's potential utility for quick SARS-CoV-2 screening.

\section{Real sample analysis}

The aptasensor that has been developed was then tested on saliva samples by standard addition with the RBD protein S SARS-CoV-2 standard. Saliva samples were taken from the same negative individual, then dissolved in buffer solution. Each saliva sample was diluted with $100 \mathrm{ng} / \mathrm{mL}$ of RBD protein S SARS-CoV-2, and then tested on the aptasensor. The resulting peak current response is entered into the equation $y=0.0448 x+0.3395$. From the calculation results, the recovery for biological samples in the form of saliva is $99.90 \%$. The results revealed that the aptasensor could detect RBD protein S SARS-CoV-2 in real samples without any preparation or preprocessing, and that it had a lot of potential as a reliable instrument for detecting SARS-COV-2 virus in real biological materials.

\section{Conclusions}

During the COVID-19 pandemic, the development of highly sensitive and rapid biosensing devices has become increasingly important. In this paper, a label-free electrochemical aptasensor for detection of RBD protein S SARS-CoV-2 has been presented as a potential approach for COVID-19 diagnosis. The disposable SPCE were AuNP-modified, and streptavidin was used to immobilize the biotinylated aptamer, which serves as a bioreceptor in the electrochemical aptasensor developed to detect the RBD protein S SARS-CoV-2. We present the novelty of using an aptamer immobilization technique at the electrode surface with an aptamer immobilization technique based on the streptavidin-biotin interaction, with specific affinity between streptavidin and biotin, through the MPA (3mercaptopropionic acid) linker. The aptasensor demonstrated excellent sensing performance in terms of sensitivity, accuracy, and fast response with the time of analysis (60 min), easiness of use, and the requirement of portable instrumentation, especially the possibility of using smartphones, boost this electrochemical aptasensor has the potential to become a Point of Care (POC) device for SARS-CoV-2 detection on clinical specimens, including nasal, nasopharyngeal swabs, or saliva.

Acknowledment: This research was supported by Indonesian Ministry of Research and Technology/National Research and Innovation Agency No.69/FI/P-KCOVID-19.2B3/IX/2020. 


\section{References}

[1] D. Schoeman, B.C. Fielding, Virology Journal 16 (2019) 1-22. https://doi.org/10.1186/$\underline{\text { s12985-019-1182-0 }}$

[2] Y. Jin, H. Yang, W. Ji, W. Wu, S. Chen, W. Zhang, G. Duan, Viruses 12 (2020). https://doi.org/ $10.3390 / \mathrm{v} 12040372$

[3] W. Tai, L. He, X. Zhang, J. Pu, D. Voronin, S. Jiang, Y. Zhou, L. Du, Cellular and Molecular Immunology 17 (2020) 613-620. https://doi.org/10.1038/s41423-020-0400-4

[4] A. C. Walls, Y. J. Park, M. A. Tortorici, A. Wall, A. T. McGuire, D. Veesler, Cell 181 (2020) 281292. https://doi.org/10.1016/i.cell.2020.02.058

[5] Y. Song, J. Song, X. Wei, M. Huang, M. Sun, L. Zhu, B. Lin, H. Shen, Z. Zhu, C. Yang, Analytical Chemistry 92 (2020) 9895-9900. https://doi.org/10.1021/acs.analchem.0c01394

[6] M. Drobysh, A. Ramanaviciene, R. Viter, A. Ramanavicius, Micromachines 12 (2021) 1-19. https://doi.org/10.3390/mi12040390

[7] F. Cui, H. Zhou, Biosensors and Bioelectronics 165 (2020) 112349. https://doi.org/10.1016/ j.bios.2020.112349

[8] Z. Chen, Q. Wu, J. Chen, X. Ni, J. Dai, Virologica Sinica 35 (2020) 351-354. https://doi.org/10.1007/s12250-020-00236-z

[9] R. Chand, S. Neethirajan, Biosensors and Bioelectronic 15 (2017) 47-53. https://doi.org/ 10.1016/i.bios.2017.06.026

[10] C.Y. Yao, W.L. Fu, World Journal of Gastroenterology 20 (2014) 12485-12492. https://doi.org/10.3748/wjg.v20.i35.12485

[11] M. Labib, A.S. Zamay, D. Muharemagic, A. V. Chechik, J. C. Bell, M. V. Berezovski, Analytical Chemistry 84 (2012) 1813-1816. https://doi.org/10.1021/ac203412m

[12] S. Mahari, A. Roberts, D. Shahdeo, S. Gandhi, BioRxiv (2020). https://doi.org/10.1101/ 2020.04.24.059204

[13] Z. Rahmati, M. Roushani, H. Hosseini, H. Choobin, Microchimica Acta 188 (2021) 1-9. https://doi.org/10.1007/s00604-021-04762-9

[14] L. Fabiani, M. Saroglia, G. Galatà, R. De Santis, S. Fillo, V. Luca, G. Faggioni, N. D'Amore, E. Regalbuto, P. Salvatori, G. Terova, D. Moscone, F. Lista, F. Arduini, Biosensors and Bioelectronics 171 (2021) 112686. https://doi.org/10.1016/i.bios.2020.112686

[15] B. Mojsoska, S. Larsen, D. Olsen, J. Madsen, I. Brandslund, F. Alatraktchi, Sensors 21 (2021) 1-11. https://doi.org/10.3390/s21020390

[16] S. Tripathy, S. G. Singh, Transactions of the Indian National Academy of Engineering. 5 (2020) 205-209. https://doi.org/10.1007/s41403-020-00103-z

[17] H. Zhao, F. Liu, W. Xie, T.C. Zhou, J. OuYang, L. Jin, H. Li, C.Y. Zhao, L. Zhang, J. Wei, Y.P. Zhang, C.P. Li, Sensors and Actuators B 327 (2021) 128899. https://doi.org/10.1016/ j.snb.2020.128899

[18] M. A. Ali, C. Hu, S. Jahan, B. Yuan, M. S. Saleh, E. Ju, S. J. Gao, R. Panat, Advanced Materials 33 (2021) 1-15. https://doi.org/10.1002/adma.202006647

[19] A. Yakoh, U. Pimpitak, S. Rengpipat, N. Hirankarn, Biosensors and Bioelectronics 176 (2021) 112912. https://doi.org/10.1016/i.bios.2020.112912

[20] A. Idili, C. Parolo, R. Alvarez-Diduk, A. Merkoçi, ACS Sensors 6 (2021) 3093-3101. https://doi.org/10.1021/acssensors.1c01222

[21] J. C. Abrego-Martinez, M. Jafari, S. Chergui, C. Pavel, D. Che, M. Siaj, Biosensors and Bioelectronics 195 (2022) 113595. https://doi.org/10.1016/i.bios.2021.113595

[22] D. H. Mohsin, M. S. Mashkour, F. Fatemi, Chemical Papers 75 (2020) 279-295. https://doi.org/10.1007/s11696-020-01292-1

[23] N. Li, Y. Wang, A. Pothukuchy, A. Syrett, N. Husain, S. Gopalakrisha, P. Kosaraju, A. D. Ellington, Nucleic Acids Research 36 (2008) 6739-6751. https://doi.org/10.1093/nar/gkn775 
[24] M. Famulok, J. Hartig, G. Mayer, Chemical Reviews 107 (2007) 3716-3737. https://doi.org/ $10.1021 / \mathrm{cr0306743}$

[25] B. Deiminiat, G. Rounaghi, M. Arbab-Zavar, I. Razavipanah, Sensors and Actuators B 242 (2017) 158-166. https://doi.org/10.1016/j.snb.2016.11.041

[26] M. Jarczewska, L. Górski, E. Malinowska, Analytical Methods 8 (2014) 3861-3877. https://doi.org/10.1039/C6AY00499G

[27] S. G. Meirinho, L. G. Dias, A. M. Peres, L. R. Rodrigues, Biotechnology Advances 34 (2016) 941-953. https://doi.org/10.1016/i.biotechadv.2016.05.006

[28] A. K. Sari, S. Gaffar, Y. W. Hartati, Analytical \& Bioanalytical Electrochemistry 14 (2022) 127-143. http://www.abechem.com/article 249328.html

[29] S. Liébana, G. A. Drago, Essays in Biochemistry 60 (2016) 59-68. https://doi.org/10.1042/ EBC20150007

[30] Y. Hartati, N. Satriana, S. Gaffar, J. Mulyana, S. Wyantuti, Y. Sofiatin, Electrochemical LabelFree Immunosensor for The Detection of Epithelial Sodium Channels Using Gold Modified Screen-Printed Carbon Electrode, in: European Alliance for Innovation, 2020. https://doi.org/10.4108/eai.11-7-2019.2298070

[31] S. Wyantuti, U. Pratomo, L. A. Manullang, D. Hendrati, Y. W. Hartati, H. H. Bahti, Heliyon 7 (2021). https://doi.org/10.1016/i.heliyon.2021.e06602

[32] S. Wyantuti, F. W. Harahap, Y. W. Hartati, M. L. Firdaus, Journal of Physics: Conference Series 1731 (2021) 012017. https://doi.org/10.1088/1742-6596/1731/1/012017

[33] Z. Kovács, C. Molnár, U. L. Štangar, V. M. Cristea, Z. Pap, K. Hernadi, L. Baia, Nanomaterials 11 (2021) 1134. https://doi.org/10.3390/nano11051334

[34] Y. W. Hartati, D. R. Komala, D. Hendrati, S. Gaffar, A. Hardianto, Y. Sofiatin, H. H. Bahti, Royal Society Open Science 8 (2021) 202040. https://doi.org/10.1098/rsos.202040.

[35] H. Shu, W. Wen, H. Xiong, X. Zhang, S. Wang, Electrochemistry Communications 37 (2013) 15-19. https://doi.org/10.1016/i.elecom.2013.09.018

[36] M. Roushania, Z. Jalilianb, A. Nezhadali, Heliyon 5 (2019) e01984. https://doi.org/10.1016/ j.heliyon.2019.e01984

[37] V. R. R. Bernardo-Boongalinga, N. Serranoa, J. J. García-Guzmánc, J. M. PalaciosSantanderc, J. M. Díaz-Cruza, Journal of Electroanalytical Chemistry 847 (2019) 113184. https://doi.org/10.1016/i.jelechem.2019.05.066

[38] Q. Gong, H. Yang, Y. Dong, W. Zhang, Analytical Methods 89 (2015) 565-569. https://doi.org/10.1039/C5AY00111K

[39] M. Shah, V. Badwaik, Y. Kherde, H. K. Waghwani, T. Modi, Z. P. Aguilar, H. Rodgers, W. Hamilton, T. Marutharaj, C. Webb, M. B. Lawrenz, R. Dakshinamurthy, Frontiers in Bioscience 19 (2014) 1320-1344. https://doi.org/10.2741/4284

[40] E. I. Fazrin, A. I. Naviardianti, S. Wyantuti, S. Gaffar, Y. W. Hartati, PENDIPA Journal of Science Education 4 (2020) 21-39. https://doi.org/10.33369/pendipa.4.2.21-39

[41] C. D. De Souza, B. R. Nogueira, M. E. C. M. Rostelato, Journal of Alloys and Compounds 798 (2019) 714-740. https://doi.org/10.1016/i.jallcom.2019.05.153

[42] H. W. Cheng, Z. R. Skeete, E. R. Crew, S. Shan, J. Luo, C. J. Zhong, Comprehensive Analytical Chemistry. 66 (2014) 37-79. https://doi.org/10.1016/B978-0-444-63285-2.00002-X

[43] S. Wyantuti, M. Permadi, D. Hendrati, Y.W. Hartati, Al-Kimia 5 (2017) 12-20. https://doi.org/10.24252/al-kimia.v5i1.2844

[44] M. P. Almeida, E. Pereira, P. Baptista, I. Gomes, S. Figueiredo, L. Soares, R. Franco, Comprehensive Analytical Chemistry 66 (2014) 529-367. https://doi.org/10.1016/B978-0444-63285-2.00013-4

[45] S. A. Akintelu, S. C. Olugbeko, A. S. Folorunso, International Nano Letters 10 (2020) 237248. https://doi.org/10.1007/s40089-020-00317-7 
[46] Novianti, R. V. Manurung, Arifin, Indonesian Journal of Electronics and Instrumentation Systems. 10 (2020) 65. https://doi.org/10.22146/ijeis.54138.

[47] S. Gaffar, D. Udamas, Y. W. Hartati, T. Subroto, AIP Conference Proceedings 2049 (2018) 19. https://doi.org/10.1063/1.5082518

[48] Y. W. Hartati, B. S. U. Misonia, W. Santhy, G. Shabarni, Research Journal of Chemistry and Environment 22 (2018) 294-301. https://worldresearchersassociations.com/Speciallssue August2018/52.pdf

[49] Z. W. Jiang, T. T. Zhao, C. M. Li, Y. F. Li, C. Z. Huang, ACS Applied Materials \& Interfaces 13 (2021) 49754-49761. https://doi.org/10.1021/acsami.1c17574

[50] J. Tian, Z. Liang, O. Hu, Q. He, D. Sun, Z. Chen, Electrochimica Acta 387 (2021) 138553. https://doi.org/10.1016/i.electacta.2021.138553

[51] H. Thakur, N. Kaur, D. Sareen, N. Prabhakar, Talanta 171 (2017) 115-123. https://doi.org/ 10.1016/i.talanta.2017.04.063

[52] C. P. McMahon, S. J. Killoran, S. M. Kirwan, R. D. O'Neill, Chemical Communications 18 (2004) 2128-2130. https://doi.org/10.1039/b408051n

[53] N. Fakhri, M. Hosseini, O. Tavakoli, Analytical Methods 10 (2018) 4438-4444. https://doi.org/10.1039/c8ay01331d

[54] B. V. Ribeiro, T. A. R. Cordeiro, G. R. O. Freitas, L. F. Ferreira, D. L. Franco, Talanta 2 (2020). 100007. https://doi.org/10.1016/i.talo.2020.100007

[55] L. Liv, Microchemical Journal 168 (2021). https://doi.org/10.1016/i.microc.2021.106445

[56] P. Panjan, V. Virtanen, A. M. Sesay, Talanta 170 (2017) 331-336. https://doi.org/10.1016/ j.talanta.2017.04.011

[57] L. C. Chen, E. Wang, C. S. Tai, Y. C. Chiu, C. W. Li, Y. R. Lin, T. H. Lee, C. W. Huang, J. C. Chen, W. L. Chen, Biosensors and Bioelectronics 155 (2020) 112111. https://doi.org/10.1016/ j.bios.2020.112111

(C)2022 by the authors; licensee IAPC, Zagreb, Croatia. This article is an open-access article distributed under the terms and conditions of the Creative Commons Attribution license (https://creativecommons.org/licenses/by/4.0/) 
